Correspondence

Walter Reineke

reineke@uni-wuppertal.de

Received 25 June 2009

Revised 4 September 2009

Accepted 8 September 2009

\section{Degradation of chloroaromatics by Pseudomonas putida GJ31: assembled route for chlorobenzene degradation encoded by clusters on plasmid pKW1 and the chromosome}

\author{
Markus Kunze, ${ }^{1} \dagger$ Kay F. Zerlin, ${ }^{1} \ddagger$ Alexander Retzlaff, ${ }^{1}$ Jens O. Pohl, ${ }^{1}$ \\ Eberhard Schmidt, ${ }^{1}$ Dick B. Janssen, ${ }^{2}$ Ramiro Vilchez-Vargas, ${ }^{3}$ \\ Dietmar H. Pieper ${ }^{3}$ and Walter Reineke ${ }^{1}$ \\ ${ }^{1}$ Bergische Universität Wuppertal, Chemical Microbiology, D-42097 Wuppertal, Germany \\ ${ }^{2}$ Department of Biochemistry, Groningen Biomolecular Sciences and Biotechnology Institute, \\ University of Groningen, 9747 AG Groningen, The Netherlands \\ ${ }^{3}$ Department of Microbial Pathogenesis, Helmholtz Centre for Infection Research, D-38124 \\ Braunschweig, Germany
}

\begin{abstract}
Pseudomonas putida GJ31 has been reported to grow on chlorobenzene using a meta-cleavage pathway with chlorocatechol 2,3-dioxygenase (CbzE) as a key enzyme. The CbzE-encoding gene was found to be localized on the $180 \mathrm{~kb}$ plasmid pKW1 in a cbzTEXGS cluster, which is flanked by transposases and encodes only a partial (chloro)catechol meta-cleavage pathway comprising ferredoxin reductase, chlorocatechol 2,3-dioxygenase, an unknown protein, 2-hydroxymuconic semialdehyde dehydrogenase and glutathione $S$-transferase. Downstream of cbzTEXGS are located $c b z J$, encoding a novel type of 2-hydroxypent-2,4-dienoate hydratase, and a transposon region highly similar to Tn5501. Upstream of cbzTEXGS, traNEOFG transfer genes were found. The search for gene clusters possibly completing the (chloro)catechol metabolic pathway of GJ31 revealed the presence of two additional catabolic gene clusters on pKW1. The mhpRBCDFETP cluster encodes enzymes for the dissimilation of 2,3-dihydroxyphenylpropionate in a novel arrangement characterized by the absence of a gene encoding 3-(3-hydroxyphenyl)propionate monooxygenase and the presence of a GntR-type regulator, whereas the nahINLOMKJ cluster encodes part of the naphthalene metabolic pathway. Transcription studies supported their possible involvement in chlorobenzene degradation. The upper pathway cluster, comprising genes encoding a chlorobenzene dioxygenase and a chlorobenzene dihydrodiol dehydrogenase, was localized on the chromosome. A high level of transcription in response to chlorobenzene revealed it to be crucial for chlorobenzene degradation. The chlorobenzene degradation pathway in strain GJ31 is thus a mosaic encoded by four gene clusters.
\end{abstract}

\section{INTRODUCTION}

Chlorinated aromatic compounds are only rarely synthesized in nature, but are produced widely through human

†Present address: Sandoz, Basel, Switzerland.

$\ddagger$ Present address: Forschungszentrum Jülich $\mathrm{GmbH}$, Geschäftsstelle BIO NRW, Düsseldorf, Germany.

Abbreviations: GST, glutathione S-transferase; 2-HMS, 2-hydroxy-5formylpent-2,4-dienoate (2-hydroxymuconic semialdehyde); MFS, major facilitator superfamily.

The GenBank/EMBL/DDBJ accession numbers for the nah cluster, mhp cluster, cbzE cluster and upper pathway cluster sequences of Pseudomonas putida GJ31 are AY831460, AY831461, AY831462 and AY831463, respectively. activities in large quantities for various purposes. Vast amounts of these compounds have been deliberately or accidentally released into the biosphere. This has raised major environmental concerns because of the low rate of microbial degradation, resulting in the persistence of these compounds in the environment and accumulation in food chains (Schwarzenbach et al., 2003; Wackett \& Hershberger, 2001). However, some bacterial strains have evolved degradative pathways for chloroaromatics and can even use these compounds as growth substrates (Reineke, 2001; Wackett \& Hershberger, 2001).

The aerobic microbial degradation of various chloroaromatic compounds occurs via chlorocatechols as central intermediates. These are usually further degraded through 
the modified ortho-cleavage pathway (Dorn \& Knackmuss, 1978a, b; Kaschabek \& Reineke, 1992; Schmidt \& Knackmuss, 1980; Schmidt et al., 1980). In contrast, Pseudomonas putida strain GJ31 has been shown to be able to degrade toluene and chlorobenzene simultaneously (Oldenhuis et al., 1989), and rapidly degrades chlorobenzene via 3-chlorocatechol using a novel type of metacleavage pathway instead of the modified ortho-cleavage pathway (Mars et al., 1997). The chlorocatechol 2,3dioxygenase CbzE of strain GJ31 productively converts 3chlorocatechol, and stoichiometric displacement of chloride leads to the production of 2-hydroxymuconate (Kaschabek et al., 1998), which is further converted through the meta-cleavage pathway. The $c b z E$ gene is localized on a 3103 bp PstI fragment of the total DNA of strain GJ31. The gene cluster encoding a ferredoxin (CbzT) and part of a 2-hydroxymuconic semialdehyde dehydrogenase $(\mathrm{CbzG})$ is preceded by a transposase gene, tmpA1
(Mars et al., 1999; Tropel et al., 2002) (Fig. 1a), and has been suggested to be localized on a large plasmid (Mars et al., 1999).

In this paper we describe the isolation of a large plasmid, pKW1, involved in chlorobenzene catabolism by $P$. putida GJ31. We report the cloning and sequence analysis of an overall length of $29.6 \mathrm{~kb}$ and identify the cluster(s) harbouring the genes that encode the meta-cleavage pathway for chlorocatechols in $P$. putida GJ31. The pathway is supported by demonstrating the functionality of key enzymes of the clusters and by transcription studies.

\section{METHODS}

Strains, plasmids, growth conditions and cell extracts. The strains and plasmids used in this study are summarized in Table 1. Escherichia coli DH5 $\alpha$ clones were grown overnight in Luria-Bertani

(a)
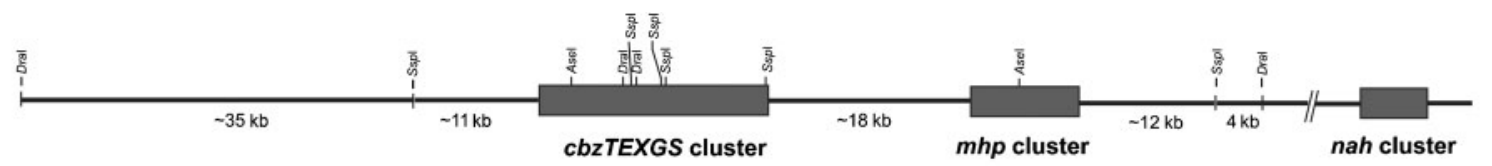

(b)
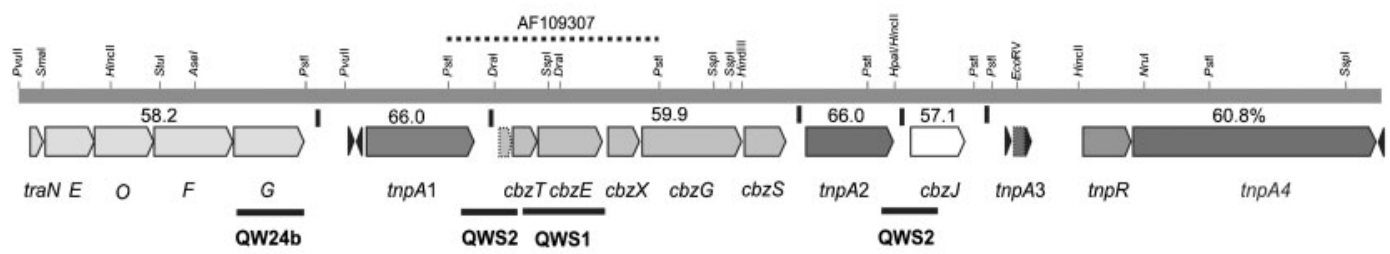

$1 \mathrm{~kb}$

(c)
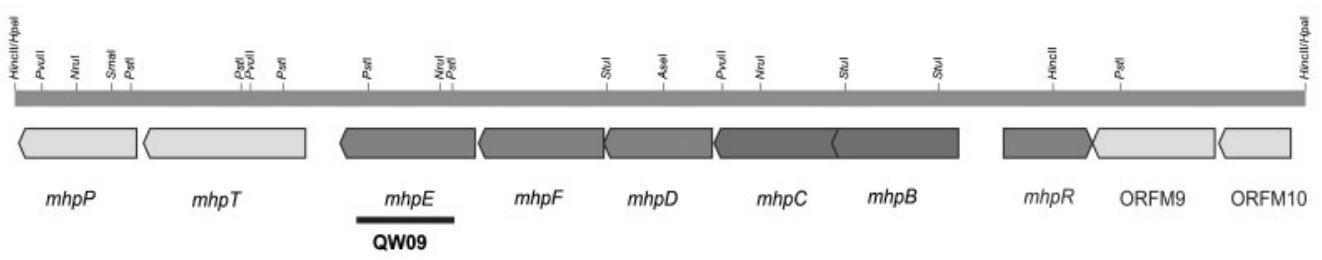

mhpF

$\operatorname{mhpC} \quad \operatorname{mhpB}$

MhPR ORFM9 ORFM10

$1 \mathrm{~kb}$

(d)

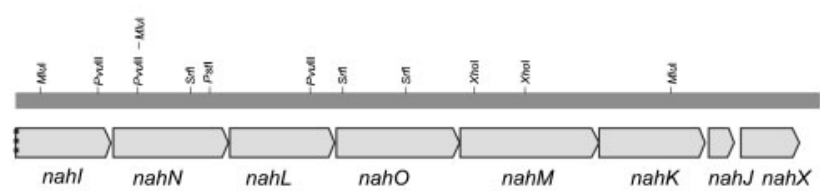

$1 \mathrm{~kb}$

(e)

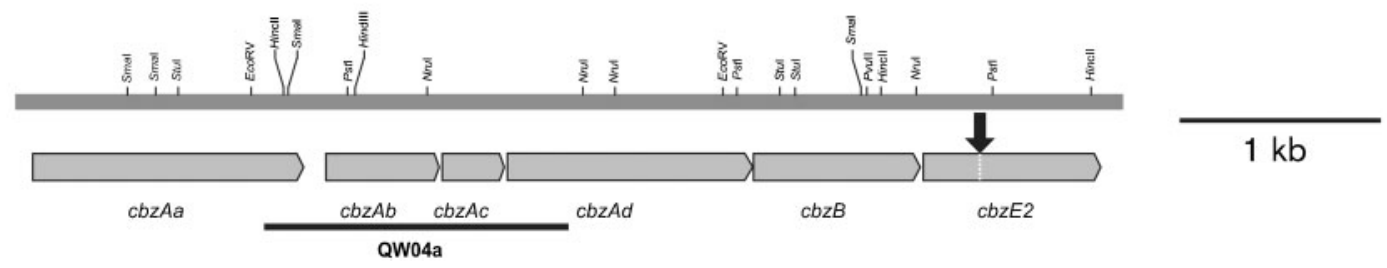

Fig. 1. Organization of the clusters encoded on plasmid pKW1 of $P$. putida strain GJ31 and the upper cluster on the chromosome. (a) Overall scheme of the $110 \mathrm{~kb}$ region on pKW1 comprising cbzE; (b) cbzTEXGS cluster, the dotted line indicates the region known from Mars et al. (1999), the $G+C$ content is indicated for regions of the cluster defined by vertical black lines; (c) mhp cluster; (d) nah cluster; (e) upper chlorobenzene gene cluster localized on the chromosome. The arrow indicates the deletion at position 277 of $c b z E 2$. The horizontal black lines show labelled probes used for hybridization. 
Table 1. Bacterial strains and plasmids used in this study

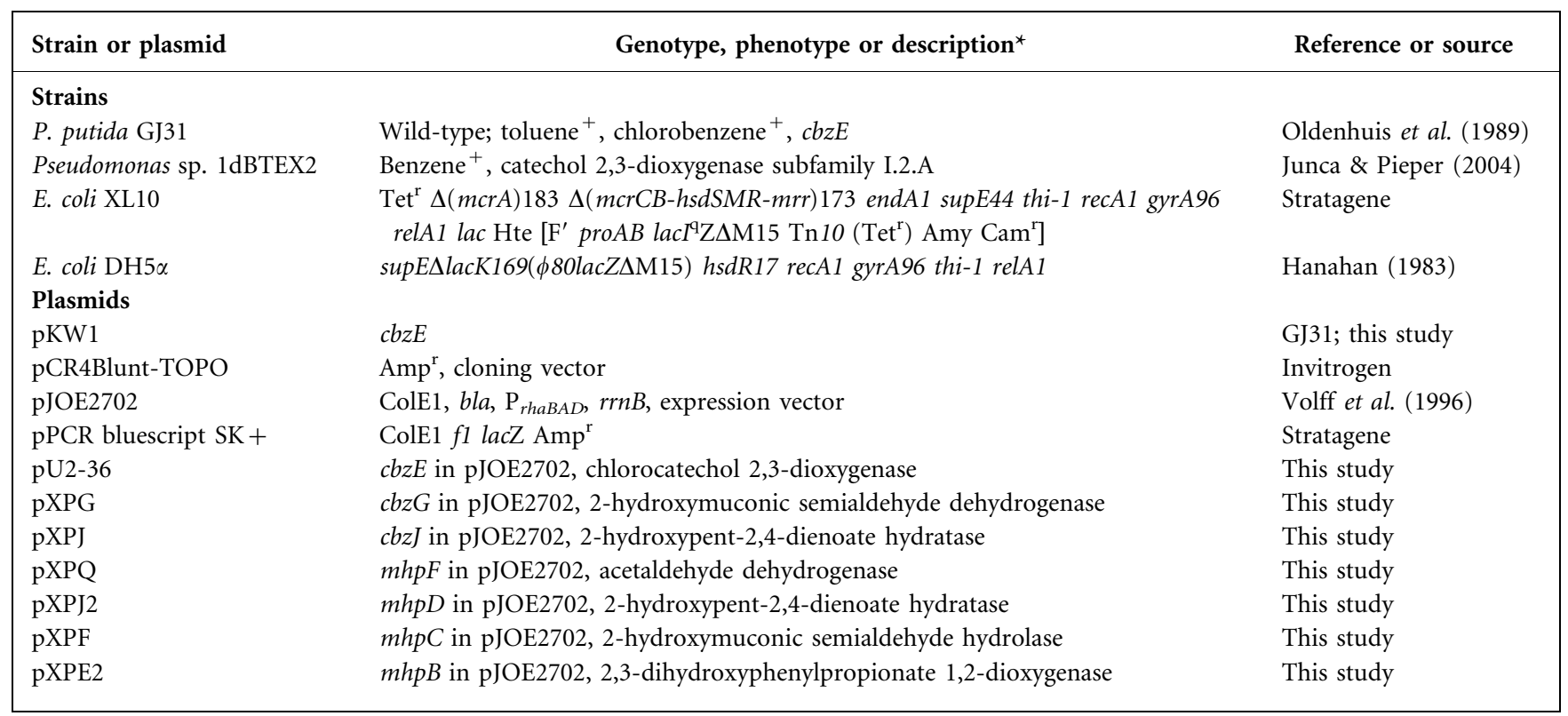

${ }^{*} \mathrm{Tet}^{\mathrm{r}}, \mathrm{Cam}^{\mathrm{r}}$ and $\mathrm{Amp}^{\mathrm{r}}$ denote resistance to tetracycline, chloramphenicol and ampicillin, respectively. toluene ${ }^{+}$, chlorobenzene ${ }^{+}$and benzene ${ }^{+}$ indicate the capability of the strain to use the respective compound as sole carbon source.

medium containing $100 \mu \mathrm{g}$ ampicillin $\mathrm{ml}^{-1}$ at $37^{\circ} \mathrm{C}$. The cells were harvested, resuspended in $0.1 \mathrm{M} \mathrm{Tris} / \mathrm{HCl}(\mathrm{pH} 7.5$ ) containing $0.1 \mathrm{mM}$ 1,4-dithiothreitol and disrupted using a French press (Aminco). The supernatant collected after centrifugation at $100000 \mathrm{~g}$ was used as the enzyme extract. P. putida GJ31 was grown as previously described (Mars et al., 1997).

Enzyme assays. All enzyme assays were performed in $50 \mathrm{mM}$ phosphate buffer ( $\mathrm{pH} 7.4$ ) at $25^{\circ} \mathrm{C}$. Reactions were started by addition of cell extract (final concentration $0.02-0.2 \mathrm{mg}$ protein $\mathrm{ml}^{-1}$ ). One unit is defined as the activity required to convert one micromole of substrate or to form one micromole of product per minute under the conditions of the assay.

Catechol 2,3-dioxygenase activity was measured by determining product formation from catechol or 3-chlorocatechol at 375 or $290 \mathrm{~nm}$, respectively $\left(\varepsilon_{2 \text {-hydroxymuconic semialdehyde }}=360001 \mathrm{~mol}^{-1}\right.$ $\mathrm{cm}^{-1} ; \varepsilon_{2 \text {-hydroxyhexa-2,4-dienedioate }}=125001 \mathrm{~mol}^{-1} \mathrm{~cm}^{-1}$; (Kaschabek et al., 1998; Nozaki, 1970). 2,3-Dihydroxyphenylpropionate 1,2-dioxygenase activity was measured by determining product formation from 2,3-dihydroxyphenylpropionate at $394 \mathrm{~nm}$

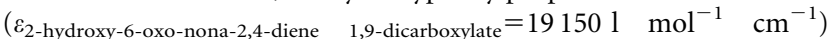
(Bugg, 1993). 2-Hydroxymuconic semialdehyde hydrolase activity was measured by determining the $\mathrm{NAD}^{+}$-independent decrease in concentration of 2-hydroxymuconic semialdehyde $(0.06 \mathrm{mM})$ at $375 \mathrm{~nm}$ (Mars et al., 1997). 2-Hydroxymuconic semialdehyde dehydrogenase activity was measured by determining the $\mathrm{NAD}^{+}$. dependent decrease in concentration of 2-hydroxymuconic semialdehyde $(0.06 \mathrm{mM})$ at $375 \mathrm{~nm}$. NAD ${ }^{+}$was added to a final concentration of $0.5 \mathrm{mM}$. Oxalocrotonate decarboxylase activity was measured at $236 \mathrm{~nm}$ by determining the decrease in concentration of oxalocrotonate $(0.1 \mathrm{mM})\left(\varepsilon_{\text {oxalocrotonate }}=6580 \mathrm{l} \mathrm{mol}^{-1} \mathrm{~cm}^{-1}\right)$ (Stanley et al., 2000). 2-Hydroxypent-2,4-dienoate hydratase activity was measured by determining the decrease in concentration at $265 \mathrm{~nm}\left(\varepsilon_{2 \text {-hydroxypent-2,4-dienoate }}=100001 \mathrm{~mol}^{-1} \mathrm{~cm}^{-1}\right.$ ) (Collinsworth et al., 1973) in the presence of $0.33 \mathrm{mM} \mathrm{MgCl}$. Acetaldehyde dehydrogenase (acylating) activity was measured by determining the coenzyme A-dependent $\mathrm{NAD}^{+}$reduction at $340 \mathrm{~nm}$ (Shingler et al., 1992). Reaction mixtures contained $10 \mathrm{mM}$ acetaldehyde, $100 \mathrm{mM}$ coenzyme $\mathrm{A}$ and $0.28 \mathrm{mM} \mathrm{NAD}{ }^{+}$. Protein concentrations were determined using the Bradford reagent with BSA as the standard (Bradford, 1976).

Purification and general manipulations of DNA. Preparation of total DNA of P. putida GJ31, Southern blot hybridization, preparation of competent $E$. coli cells and subsequent transformations were performed as described elsewhere (Sambrook et al., 1989). Plasmid DNA was isolated by the method of Wheatcroft \& Williams (1981). Pure plasmid DNA was obtained by subsequent CsClethidium bromide centrifugation. DNA restriction digests were performed according to the instructions of the manufacturers (Roche Diagnostics, New England Biolabs).

Cloning in E. coli. Genes were amplified from DNA of $P$. putida GJ31 using primers annealing upstream and downstream of the target genes, and including artificial $\mathrm{NdeI}$ and a BamHI sites, respectively (see Table 2). Amplification was performed using Advantage cDNA polymerase mix (Clontech). After confirmation of the sequences, the fragments were cloned into the respective restriction sites of pJOE2702, and E. coli $\mathrm{DH} 5 \alpha$ was transformed with the resultant plasmid.

PCR amplification. The reaction mixtures $(50 \mu \mathrm{l})$ contained $50 \mathrm{pmol}$ of each primer (see Table 2), $0.5 \mu \mathrm{g}$ total or plasmid template DNA, $200 \mu \mathrm{M}$ of each dNTP, $1 \times$ PCR buffer (Stratagene), $5 \%$ DMSO and 2.0 U Advantage DNA polymerase (Stratagene). PCR was performed with a touchdown thermocycle program: initial denaturation $\left(98{ }^{\circ} \mathrm{C}, 1 \mathrm{~min}\right)$ before addition of the polymerase; $25-30$ cycles with stepwise decreasing annealing temperature $\left(60-50{ }^{\circ} \mathrm{C}\right.$; $30 \mathrm{~s})$, polymerization $\left(68{ }^{\circ} \mathrm{C}, 1 \mathrm{~min}\right.$ per $\left.1000 \mathrm{nt}\right)$, and denaturation $\left(98{ }^{\circ} \mathrm{C}, 45 \mathrm{~s}\right.$ ); with an additional $5 \mathrm{~min}$ of elongation during the last cycle. To obtain blunt-ended PCR products, Klenow fragment was 
Table 2. Primers used in this study

\begin{tabular}{|c|c|c|c|c|}
\hline Primer & Sequence $\left(5^{\prime}-3^{\prime}\right)^{\star}$ & $\begin{array}{c}\text { Amplicon size } \\
\text { (bp) }\end{array}$ & Target/probe & Reference or source \\
\hline Qno22 & AGGGTTCGTTTCATCAACGAACGAG & 1043 & $c b z E /$ probe QWS1 & This study \\
\hline Qno23 & CAAGCTGATGAATCAAGACTTGGGG & & & \\
\hline Qno24 & ATCAGCGCGTCAGTTGGTAG & 673 & $\begin{array}{l}\text { tnpA1 downstream region/probe } \\
\text { QWS2 }\end{array}$ & This study \\
\hline Qno25 & TGCAGCAGACTCTCATCCGT & & & \\
\hline Qno13 & GGCGAGGCGAAGTTCTACATGGACC & 2819 & $c b z A a A b A c A d /$ probe QW04 & This study \\
\hline Qno14 & CATYTGCATBCGATGCCCRGCRATC & & & \\
\hline Qno09 & CGAGATCCAGCACATCCTGCGAGGCCACAA & 1517 & $c b z A a A b A c A d /$ probe QW04a & This study \\
\hline Qno10 & TCCGCAGAGAGCGTGGTGCCATCATCCAGA & & & \\
\hline Qno26 & ARGTSACCCACGGYGAYGGC & 733 & $c b z K /$ probe QW09 & This study \\
\hline Qno27 & MRTAGACSCCSGCRTARCCC & & & \\
\hline Qno32 & CATGGACATGGCCCTGGCGGCGGCGAACTT & 961 & $\operatorname{traG/probe~QW24b~}$ & This study \\
\hline Qno33 & CGGGTCGTACAGGATTTCCAGCACTTCACG & & & \\
\hline Kay4 & CATGACATCCMCAAGGTSAC & 684 & nahK (fragment) & This study \\
\hline Kay5 & GCGCACSGTGATGTTGTCGC & & & \\
\hline ESP1 & GATACACATATGAGTATTATGAGAGTTGGC & 970 & $c b z E$ (cloning in pJOE2702) & This study \\
\hline ESEP3 & CACTGGTCATTGGATCCATCATGTGTACAC & & & \\
\hline cbzG-XP-1 & TCAAGAGAGAGACATATGAAAGACATCAGG & 1494 & $c b z G$ (cloning in pJOE2702) & This study \\
\hline cbzG-XP-2 & AATGGGGGCACA $\overline{\text { GGATCCTCAATAC }}$ & & & \\
\hline cbzJ-XP-1 & AGCCCCATATGACCCAGACGCCCAA & 846 & $c b z J$ (cloning in pJOE2702) & This study \\
\hline cbzJ-XP-2 & ACCGGGTTGATGTGCAGGGGATCCG & & & \\
\hline mphF-XP-1 & TTTCATATGACTACCAAACGTAAAGTTGCC & 974 & $m p h F$ (cloning in pJOE2702) & This study \\
\hline mphF-XP-2 & GAGCTTTTTACGGATCCTAACTGCGCT & & & \\
\hline mphD-XP-3 & TCACATATGAACACTTCACAAGAGACCCTT & 849 & $m p h D$ (cloning in pJOE2702) & This study \\
\hline mphD-XP-4 & AGCCAAGGATCCCAACTTTACGTTTGGTAG & & & \\
\hline mphC-XP-1 & TCCCATATGGATCGCAGGCTTCGGCTCTAT & 959 & $m p h C$ (cloning in pJOE2702) & This study \\
\hline mphC-XP-2 & TGTGAAGTGTCCATGCGGATCCTCGGTCAG & & & \\
\hline mphB-XP-1 & GTACATATGAACGCTTACCTACATTGCCTG & 983 & $m p h B$ (cloning in pJOE2702) & This study \\
\hline mphB-XP-2 & TGCAGTCACGATTAAGGATCCGTGAAGGTG & & & \\
\hline NahOMod-1 & GATCGAGGACAGCCATATGAGCAAGA & 1001 & nahO (cloning in pJOE2702) & This study \\
\hline NahOMod-2 & TCGCGCAGGATCCTGTCGTGCAGGGT & & & \\
\hline Exdo-A-F & ATGAAVAAAGGHGTWHTGCGHCCMGG & $421 / 716$ & $n a h H$ (fragment) & $\begin{array}{l}\text { H. Junca, personal } \\
\text { communication; } \\
\text { Junca \& Pieper } \\
\text { (2004) }\end{array}$ \\
\hline Exdo-A-R1 & GYGGCCADGCYTCNGGRTTG & & & \\
\hline Exdo-A-R719 & TCGATVGAKGTRTCGGTCATG & & & \\
\hline Exdo-A-F2 & CATGACCGAYACMTCBATCG & 1061 & nahHI (fragment) & This study \\
\hline NahI-R1 & ACAGTCGGCGAAGACGATGC & & & \\
\hline CbzERNAF & TGATGCGCCGACTCCC & 262 & $c b z E$ (expression studies) & This study \\
\hline CbzERNAR & AACTGCGCGACCCGCTTGA & & & \\
\hline MphBRNAF & TTATTGGGCATTTCGACCCA & 382 & $m p h B$ (expression studies) & This study \\
\hline MphBRNAR & CAGTTCACGAAAACAGGAAG & & & \\
\hline MphERNAF & CATACCGGAAAGGCTGACAT & 332 & $m p h E$ (expression studies) & This study \\
\hline MphERNAR & ATGTGTCGAAGCAGCACATC & & & \\
\hline NahLRNAF & GAGGACGCCTACCACATCTC & 250 & nahL (expression studies) & This study \\
\hline NahLRNAR & CCATCAGGTCCTTCTTGAGG & & & \\
\hline bphAF668-3 & GTTCCGTGTAACTGGAARTWYGC & 535 & $c b z A a$ (expression studies) & Witzig et al. (2006) \\
\hline bphAR1153-2 & CCAGTTCTCGCCRTCRTCYTGHTC & & & \\
\hline GltARNAF & GCCGATTTCATCCAGCATGGTC & 200 & $g l t A$ (expression studies) & $\begin{array}{l}\text { P. Bielecki, personal } \\
\text { communication }\end{array}$ \\
\hline GltARNAR & TGGACCGGATCTTCATCCTCCA & & & \\
\hline
\end{tabular}

${ }^{\star}$ Restriction sites are underlined. 
incubated with the PCR reaction mixture for $30 \mathrm{~min}$ at $4{ }^{\circ} \mathrm{C}$. Amplified template was purified with the Qiaquick PCR Purification kit (Qiagen).

PCR-based walking in DNA upstream and downstream from a known sequence was performed with the Universal Genome Walking kit and Advantage-GC cDNA PCR kit (BD Biosciences Clontech). Walks were extended by taking multiple steps using new primers based on the sequences obtained in previous steps. Primers to search for the presence of a catechol 2,3-dioxygenase of subfamily I.2.A (Eltis \& Bolin, 1996) were designed based on a multiple sequence alignment of currently available members of this subfamily (Junca \& Pieper, 2004). Primers were obtained from MWG-Biotech.

Extraction of mRNA, cDNA synthesis and RT-PCR. For gene expression studies, $P$. putida strain GJ31 was grown in mineral salt medium with chlorobenzene (corresponding to $5 \mathrm{mM}$, supplied via the vapour phase) as the sole carbon source. To assess constitutive expression, the strain was grown in parallel on fructose $(5 \mathrm{mM})$. During exponential growth, $25 \mathrm{ml}$ of each culture was mixed with the same volume of RNAprotect Bacteria reagent (Qiagen) and incubated for $5 \mathrm{~min}$ at room temperature, and cells were harvested by centrifugation. Harvested cells were resuspended in $100 \mu \mathrm{l}$ water and immediately processed as previously described (Witzig et al., 2007). cDNA was synthesized from $10 \mu \mathrm{g}$ total RNA using SuperScript III reverse transcriptase (Invitrogen) according to the procedure from the manufacturer, followed by purification of cDNA using a Qiaquick PCR purification kit (Qiagen). RT-PCR was performed with $100 \mathrm{ng}, 25 \mathrm{ng}$ and serial dilutions thereof (twofold) as template using 35 cycles, an annealing temperature of $64{ }^{\circ} \mathrm{C}$ and (i) the primer set CbzERNAF/CbzERNAR (annealing temperature $64{ }^{\circ} \mathrm{C}$ ) to amplify a $262 \mathrm{bp} c b z E$ gene fragment, (ii) the primer set MphBRNAF/MphBRNAR to amplify a 382 bp $m p h B$ gene fragment, (iii) the primer set MphERNAF/MphERNAR to amplify a $332 \mathrm{bp}$ $m p h E$ gene fragment, (iv) the primer set NahLRNAF/NahLRNAR to amplify a $250 \mathrm{bp}$ nahL gene fragment, (v) the primer set bphA F668-3/bphA R1153-2 (Witzig et al., 2006) to amplify a $535 \mathrm{bp}$ $c b z A a$ gene fragment, and (vi) the primer set GltARNAF/GltARNAR to amplify a $200 \mathrm{bp} g l t A$ gene fragment. Amplification products were separated on $1 \%$ agarose gels and stained with ethidium bromide.

DNA sequence analysis. DNA sequencing was performed by MWG-Biotech, Ebersberg, Germany. Assembled contigs were used for DNA and protein similarity searches in GenBank databases performed with the BLASTN and BLASTP programs of the National Center for Biotechnology Information website (http://ncbi.nlm.nih. gov). Translated protein sequences were aligned with CLUSTAL_X 1.83 using default values. Phylogenetic trees were constructed with MEGA4 (Tamura et al., 2007) using the Neighbour-Joining (N-J) algorithm (Saitou \& Nei, 1987) with p-distance correction and pairwise deletion of gaps and missing data. A total of 100 bootstrap replications were done to test for branch robustness.

Chemicals. Catechol derivatives were obtained from our laboratory stock and were purified by sublimation prior to use. 2-Hydroxy-5formylpent-2,4-dienoate (2-hydroxymuconic semialdehyde; 2-HMS) was prepared in situ by incubation of a solution containing $0.1 \mathrm{mM}$ catechol in $45 \mathrm{mM}$ phosphate buffer ( $\mathrm{pH} 7.4$ ) with heat-treated cell extract of $m$-toluate-grown $P$. putida mt-2. 2-Hydroxymuconate was prepared as previously described (Kaschabek et al., 1998) and further converted due to spontaneous reaction in buffer at $\mathrm{pH} 7.4$ to give oxalocrotonate. 2-Hydroxypent-2,4-dienoate was prepared from DLallylglycine using L-amino acid oxidase, as described by Collinsworth et al. (1973). 2,3-Dihydroxyphenylpropionate was obtained from Professor Timothy D. H. Bugg, University of Warwick.
RESULTS

\section{The chlorocatechol gene cluster is localized on plasmid pKW1}

In order to obtain information on the localization of the chlorocatechol gene cluster of $P$. putida GJ31 with the $c b z E$ gene encoding chlorocatechol 2,3-dioxygenase as the key gene, identification of plasmids was performed. The presence of a single plasmid, termed pKW1, could be demonstrated, with a size of $180 \pm 10 \mathrm{~kb}$ as determined by digestion with a range of restriction enzymes. Hybridization of a $1 \mathrm{~kb} c b z E$ gene fragment (QWS1) harbouring a DraI restriction site, with two DraI/SspI fragments $(0.7$ and $2.3 \mathrm{~kb})$ of the plasmid, confirmed that $c b z E$ is localized on plasmid pKW1.

\section{The gene regions flanking $c b z E$ comprise transfer genes and transposable elements}

Sequences surrounding the previously described $3103 \mathrm{bp}$ PstI fragment comprising the $c b z E$ gene (Mars et al., 1999) (see Fig. 1a) were obtained by genome walking. Successive cloning and sequencing allowed the isolation of $6.3 \mathrm{~kb}$ upstream of the previously described tnpA1 and $10.9 \mathrm{~kb}$ downstream of $c b z G$.

The predicted amino acid sequences of traN, traE, traO, traF and traG (Fig. 1b) show remarkably high sequence similarity to Tra proteins (Table 3 ), which are responsible for mobilization and transfer of DNA (Pohlman et al., 1994). A sequence of $262 \mathrm{bp}$ identical to the ' $\Delta \mathrm{xIS}$ element' of plasmid pAM10.6 of Pseudomonas fluorescens strain Cb36 (Peters et al., 1997) follows traG. This sequence is flanked by two inverted repeats, IR1 'left' and IR1 'right' (38 nt in length, 36 identical, positions $4814-4851$ and 5038-5075), typical of the Tn3 family of elements (Sherratt, 1989) (Fig. 2). The next ORF downstream, termed $\operatorname{tnp} A 1$, resembled transposase-encoding genes and is identical in amino acid sequence to the corresponding deduced gene product of Acidovorax sp. JS42 (YP_974115).

The following sequence stretch has been analysed previously (Mars et al., 1999) and comprises $c b z T, c b z E$ and $c b z X$, encoding ferredoxin reductase, chlorocatechol 2,3dioxygenase and a protein of unknown function, respectively.

The deduced amino acid sequence (486 aa) of $c b z G$ shows significant sequence similarities to 2-hydroxymuconic semialdehyde dehydrogenases, particularly to those of strains documented to possess a catechol 2,3-dioxygenase of subfamily I.2.C (Eltis \& Bolin, 1996), which is also the subfamily to which CbzE belongs. Operons that contain a gene encoding a subfamily I.2.C catechol 2,3-dioxygenase, such as that of Cupriavidus necator JMP134 (Fig. 2), usually have a quite conserved gene structure of ORFs encoding a ferredoxin, a catechol 2,3-dioxygenase, an unknown protein and a 2-hydroxymuconic semialdehyde dehydrogenase. Cell extracts of E. coli (pXPG) overexpressing $c b z G$ 
Table 3. ORFs identified in P. putida GJ31

$\mathrm{ND}$, Not determined: gene incomplete.

\begin{tabular}{|c|c|c|c|c|c|c|c|c|}
\hline \multicolumn{3}{|c|}{ Gene } & \multicolumn{3}{|r|}{ Gene product } & \multicolumn{3}{|c|}{ Closest homologue } \\
\hline ORF & $\begin{array}{l}\text { Coordinates } \\
\left(5^{\prime}-3^{\prime}\right)\end{array}$ & $\begin{array}{c}\mathrm{G}+\mathrm{C} \text { content } \\
(\%)\end{array}$ & $\begin{array}{l}\text { Number } \\
\text { of residues }\end{array}$ & $\begin{array}{l}\text { Molecular } \\
\text { mass }(\mathrm{kDa})\end{array}$ & Function & $\begin{array}{c}\text { Sequence } \\
\text { identity (\%) }\end{array}$ & Organism & $\begin{array}{c}\text { Accession } \\
\text { number }\end{array}$ \\
\hline \multicolumn{9}{|c|}{$\begin{array}{l}\text { pKW1: } c b z T E X G S \\
\text { cluster }\end{array}$} \\
\hline $\operatorname{traN}$ & 203-394 & 58.3 & 63 & 6.48 & Transfer protein & 58 & Salmonella typhimurium & NP_511194 \\
\hline $\operatorname{traE}$ & $391-1113$ & 57.7 & 240 & 26.98 & DNA topoisomerase III & 46 & Salmonella typhimurium & NP_511195 \\
\hline $\operatorname{traO}$ & $1113-1991$ & 56.0 & 292 & 32.53 & Transfer protein & 49 & Salmonella typhimurium & NP_511196 \\
\hline $\operatorname{traF}$ & $1988-3145$ & 59.8 & 385 & 41.29 & Transfer protein & 44 & Salmonella typhimurium & NP_511197 \\
\hline $\operatorname{traG}$ & $3157-4188$ & 59.5 & 343 & 38.09 & Transfer protein & 86 & P. putida $\mathrm{H}$ & AF130439 \\
\hline $\operatorname{tnp} A 1$ & $5101-6681$ & 66.0 & 526 & 57.98 & Transposase & 99 & Acidovorax sp. JS42 & YP974115 \\
\hline$c b z T$ & $7246-7605$ & 58.6 & 120 & 12.75 & Ferredoxin & 100 & P. fluorescens SK1 & AAP51202 \\
\hline$c b z E^{*}$ & $7617-8561$ & 55.7 & 315 & 34.95 & Chlorocatechol 2,3-dioxygenase & 97 & P. fluorescens SK1 & AAP51203 \\
\hline$c b z X$ & $8642-9106$ & 64.7 & 155 & 15.72 & Unknown & 100 & P. fluorescens SK1 & AAP51204 \\
\hline$c b z G^{*}$ & $9144-10604$ & 58.8 & 486 & 52.45 & 2-HMS dehydrogenase & 100 & P. fluorescens SK1 & AAP51205 \\
\hline$c b z S$ & $10644-11252$ & 55.7 & 204 & 22.08 & GST & 100 & Pseudomonas sp. CT14 & YP_001966313 \\
\hline $\operatorname{tnp} A 2$ & $11556-12833$ & 66.0 & $425(526) \dagger$ & 54.49 & Transposase & 99 & Acidovorax sp. JS42 & YP974115 \\
\hline$c b z J^{*}$ & $13085-13879$ & 57.1 & 264 & 28.51 & 2-Hydroxypent-2,4-dienoate hydratase & 99 & Acidovorax sp. JS42 & YP974116 \\
\hline $\operatorname{tnp} A 3$ & $14595-14753$ & & 106 & & Transposase fragment & & & \\
\hline $\operatorname{tnp} R$ & $16713-17312$ & 65.4 & 200 & 21.88 & Resolvase & 94 & Pseudomonas sp. ND6 & NP_943127 \\
\hline $\operatorname{tnp} A 4$ & $17296-20325$ & 60.7 & 1009 & 115.37 & Transposase & 99 & Pseudomonas sp. CT14 & YP_001966298 \\
\hline \multicolumn{9}{|c|}{ pKW1: $m h p$ cluster } \\
\hline$m h p P$ & $881-3$ & 54.7 & $293(427) \dagger$ & 32.62 & Membrane porin OprD family & 58 & Azotobacter vinelandii $\mathrm{AvOP}$ & ZP_00419203 \\
\hline$m h p T$ & $2142-926$ & 56.6 & 403 & 41.81 & MFS family transporter protein & 61 & Azotobacter vinelandii AvOP & ZP_00416222 \\
\hline$m h p E$ & $3422-2412$ & 57.4 & 336 & 36.16 & 4-Hydroxy-2-oxovalerate aldolase & 88 & P. putida W619 & YP_001748854 \\
\hline$m h p F^{*}$ & $4372-3434$ & 56.4 & 312 & 32.71 & Acetaldehyde dehydrogenase & 84 & P. putida PaW630 & AAL83664 \\
\hline$m h p D^{*}$ & $5181-4369$ & 71.1 & 270 & 28.07 & 2-Hydroxypent-2,4-dienoate hydratase & 77 & P. putida W619 & YP_001748852 \\
\hline$m h p C^{*}$ & $5940-5194$ & 55.2 & 248 & 27.59 & 2-HMS hydrolase & 82 & P. putida W619 & YP_001748851 \\
\hline$m h p B^{*}$ & $7121-6075$ & 58.1 & 315 & 34.53 & $\begin{array}{l}\text { 2,3-Dihydroxyphenylpropionate } 1,2 \text { - } \\
\text { dioxygenase }\end{array}$ & 95 & P. putida ML2 & AAG09232 \\
\hline$m h p R$ & $7358-8023$ & 52.6 & 221 & 24.52 & GntR family regulator & 53 & Dechloromonas aromatica $\mathrm{RCB}$ & YP_284124 \\
\hline ORFM9 & $8935-8018$ & 51.4 & 305 & 33.76 & Unknown & 53 & Marinobacter algicola D6839 & ZP_01895523 \\
\hline ORFM10 & $9503-8964$ & 53.3 & 179 & 19.30 & Unknown & 48 & Rhizobium sp. NGR234 & AAQ87234 \\
\hline \multicolumn{9}{|c|}{ pKW1: $n a h$ cluster } \\
\hline nahI & $1-711$ & 66.9 & $236(486) \dagger$ & $\mathrm{ND}$ & 2-HMS dehydrogenase & 99 & P. stutzeri OM1 & BAA31265 \\
\hline$n a h N$ & $723-1586$ & 67.4 & 288 & 31.90 & 2-HMS hydrolase & 96 & P. stutzeri AN10 & AAD02150 \\
\hline$n a h L$ & $1583-2368$ & 65.4 & 261 & 27.90 & 2-Hydroxypent-2,4-dienoate hydratase & 97 & P. putida MT53 & YP_709325 \\
\hline nahO & $2383-3306$ & 65.4 & 308 & 33.02 & Acetaldehyde dehydrogenase & 99 & P. stutzeri AN10 & AAD021520 \\
\hline nahM & $3318-4358$ & 65.3 & 347 & 37.27 & 4-Hydroxy-2-oxovalerate aldolase & 100 & P. stutzeri AN10 & AAD02153 \\
\hline$n a h K$ & $4355-5149$ & 62.5 & 264 & 28.56 & 4-Oxalocrotonate decarboxylase & 97 & P. stutzeri AN10 & AAD02154 \\
\hline
\end{tabular}




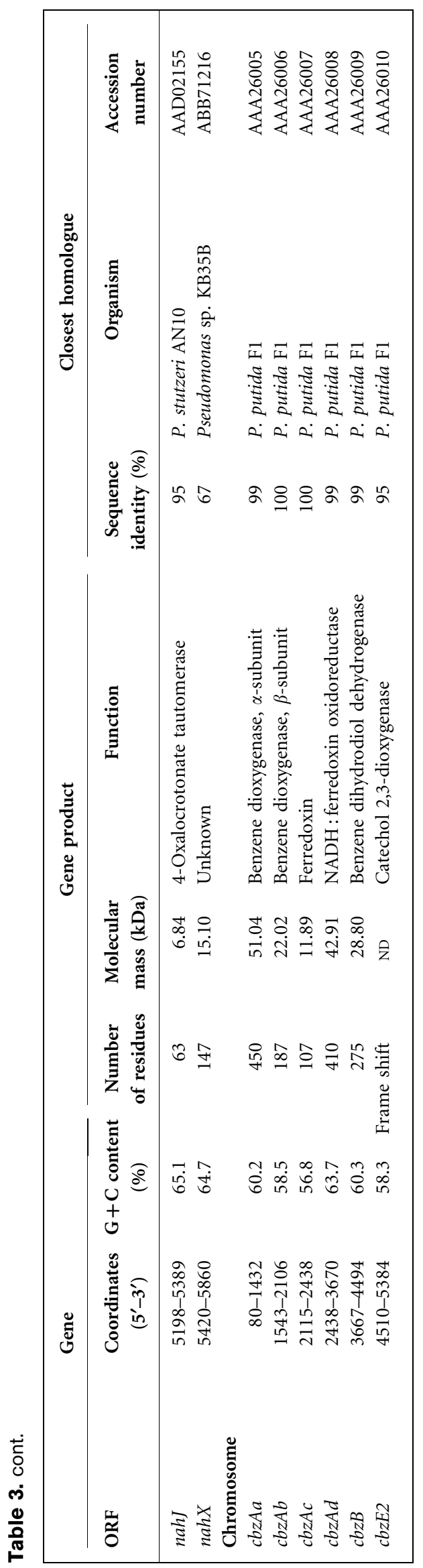

showed a strong 2-hydroxymuconic semialdehyde dehydrogenase activity of 1800 units (g protein $)^{-1}$, which was absent in $E$. coli (pJOE2702), indicating that $c b z G$ encodes a functional 2-hydroxymuconic semialdehyde dehydrogenase.

The deduced 204 aa protein encoded by $c b z S$ is similar to BphK, a glutathione S-transferase (GST) that occurs in some biphenyl pathways such as those of Burkholderia xenovorans strain LB400 and Pseudomonas pseudoalcaligenes strain KF707 (69-70\% amino acid identity) (Bartels et al., 1999). The catabolic genes are followed by tnpA2, identical in sequence to tnpA1; however, the initial $140 \mathrm{nt}$ of $\operatorname{tnpA1}$ were absent in $\operatorname{tnp} A 2$.

The protein encoded by $c b z J$ shows sequence similarities to 4-oxalocrotonate decarboxylases $(31 \%$ sequence identity with XylI of $P$. putida mt-2, CAC86800), but also to 2hydroxypent-2,4-dienoate hydratases (35\% sequence identity with XylJ of $P$. putida mt-2, P23107), enzymes catalysing subsequent reactions in catechol meta-cleavage pathways, but sharing significant amino acid similarities (see Fig. 3). For CbzJ, a high similarity was observed only to the non-characterized proteins of Acidovorax sp. JS42 (YP_974116) and Pseudomonas sp. CT14 (ABA25976), or the truncated proteins of Comamonas sp. CNB1 (ABB13584) and Delftia sp. AN3 (ABI20724). Phylogenetic analyses (Fig. 3) show that these proteins constitute a novel branch in the phylogeny of members of the tautomerase superfamily (Poelarends et al., 2008). A significant 2-hydroxypent-2,4-dienoate hydratase activity of 1100 units $(\mathrm{g} \text { protein })^{-1}$ and the absence of 4oxalocrotonate decarboxylase activity in cell extracts of $E$. coli (pXPJ) prove that CbzJ functions as a 2-hydroxypent2,4-dienoate hydratase.

A sequence of $106 \mathrm{bp}$ of the terminal repeat of part of IS 1071 was found upstream of a truncated tnpA3 (Fig. 2), the predicted encoded peptide being identical with the Nterminal portion of TnpA of IS1071 of Pseudomonas sp. strain $\mathrm{H}$ and Comamonas testosteroni strain BR60 (Providenti et al., 2006; Sota et al., 2006). At 159 bp downstream of the $\operatorname{tnp} A 3$ start codon, an inverted repeat of $38 \mathrm{nt}$ (IR2 'left'), identical to that of transposon Tn5501 (Lauf et al., 1998) (28\% identical nucleotides to IS1 'left'), disrupts the $\operatorname{tn} p A 3$ gene. The second repeat (IR2 'right') ( $26 \%$ identical nucleotides to IS1 'right') was observed about $5.5 \mathrm{~kb}$ downstream. The complete sequence stretch between these repeats on pKW1 was highly similar (97\% nucleotide sequence identity) to that observed on plasmid pPGH1 of P. putida strain H (Lauf et al., 1998), probably encoding a resolvase (TnpR, $91 \%$ amino acid identity) and a transposase (TnpA4, $88 \%$ amino acid sequence identity) of the Tn 3 family of transposases.

A gene region similar to the above-mentioned

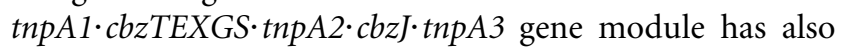
been observed on plasmid pCT14 of Pseudomonas sp. strain CT14 (Bramucci et al., 2006). In contrast to pKW1, the plasmid pCT14 lacks most of the genes (except traJ and traI) necessary for self-mobilization. 

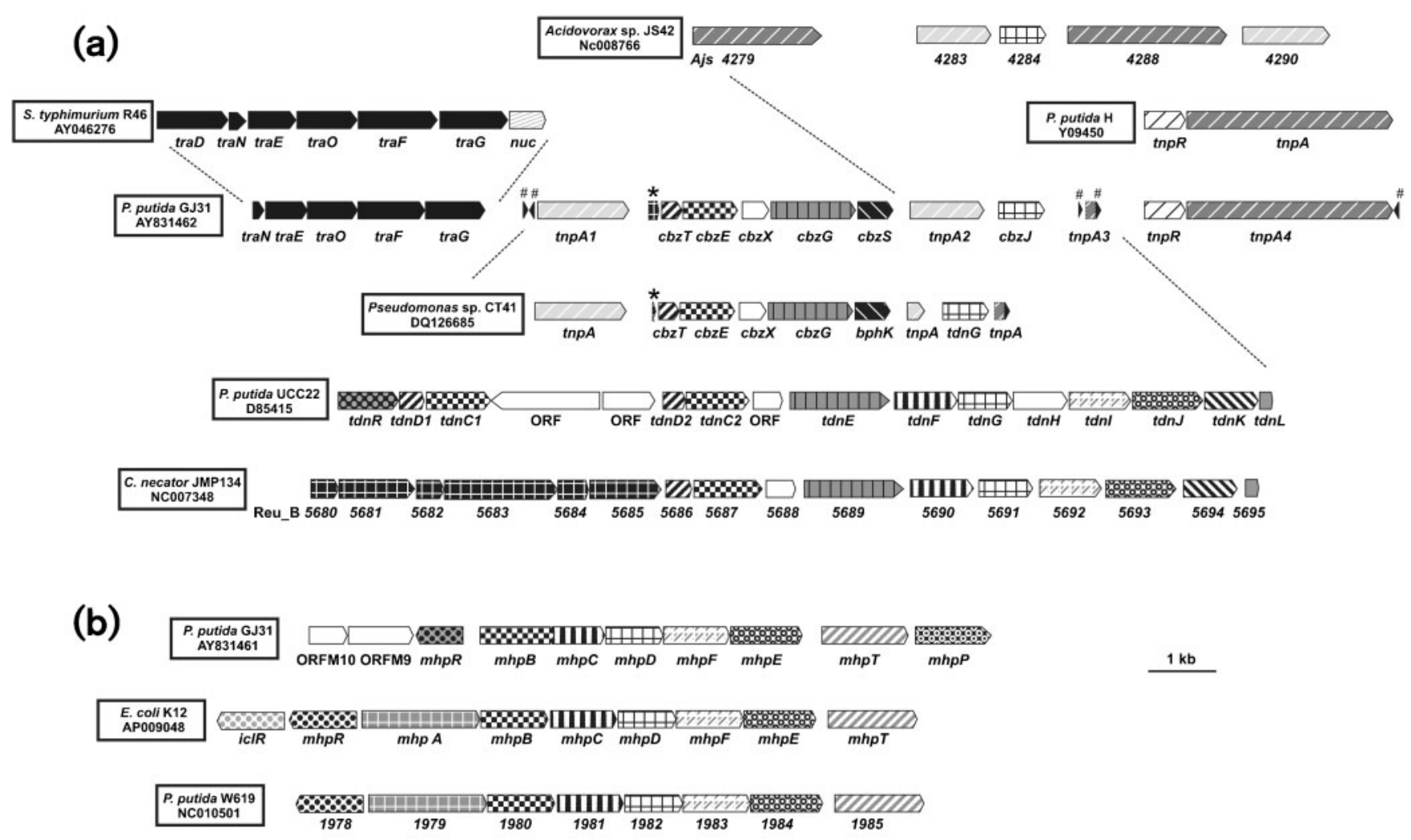

\begin{tabular}{lllll}
\hline WII Ferredoxin & Hydroxypentdienoate hydratase & Phenol hydroxylase \\
subunit, incomplete
\end{tabular}

Fig. 2. Organization of the cbzTEXGS cluster (a) and the $m h p$ gene cluster (b) in comparison with related gene clusters.

\section{Plasmid pKW1 harbours a \\ 2,3-dihydroxyphenylpropionate gene cluster}

Only some of the meta-pathway enzymes, which are necessary for 3-chlorocatechol mineralization, were encoded on the region of plasmid pKW1 described above, and those encoding oxalocrotonate tautomerase, oxalocrotonate decarboxylase, 4-hydroxy-2-oxovalerate aldolase and acetaldehyde dehydrogenase were absent (Fig. 4). The use of primers Qno26 and Qno27 targeting conserved regions of 4-hydroxy-2-oxovalerate aldolases encoded in 2,3-dihydroxyphenylpropionate meta-cleavage pathway clusters of E. coli allowed the amplification of a $730 \mathrm{bp}$ fragment from plasmid DNA. The deduced amino acid sequence showed $84 \%$ identity with 4-hydroxy-2-oxovalerate aldolase of E. coli strain K-12 (Ferrandez et al., 1997) and the respective ORF was termed $m h p E$. A total of $2.8 \mathrm{~kb}$ downstream and $6.1 \mathrm{~kb}$ upstream of the $m h p E$ gene were analysed by genome walking. DNA sequence analysis of the
9632 bp region showed nine ORFs plus an incomplete one. The encoded proteins showed high similarity to proteins of the 2,3-dihydroxyphenylpropionate meta-cleavage pathway (Diaz et al., 2001), and the gene organization resembled that observed in E. coli strain K-12 (Ferrandez et al., 1997) or P. putida strain W619 (NC_010501).

Overall, five catabolic genes $(m h p B, C, D, F$ and $E)$ could be identified (Fig. 1c). $m h p B$ encodes a polypeptide (315 aa) which shows significant sequence similarities to enzymes with a validated function as 2,3-dihydroxyphenylpropionate 1,2-dioxygenases (Diaz et al., 2001). 2,3Dihydroxyphenylpropionate 1,2-dioxygenases belong to the LigB superfamily of extradiol dioxygenases and show a broad specificity with catechol and methylcatechols as accepted substrates (Barnes et al., 1997; Diaz et al., 2001). Enzyme assays in cell extracts of E. coli (pXPE2) showed strong catechol 2,3-dioxygenase activity [1830 units ( $g$ protein $)^{-1}$ ] as compared with those of the controls. 


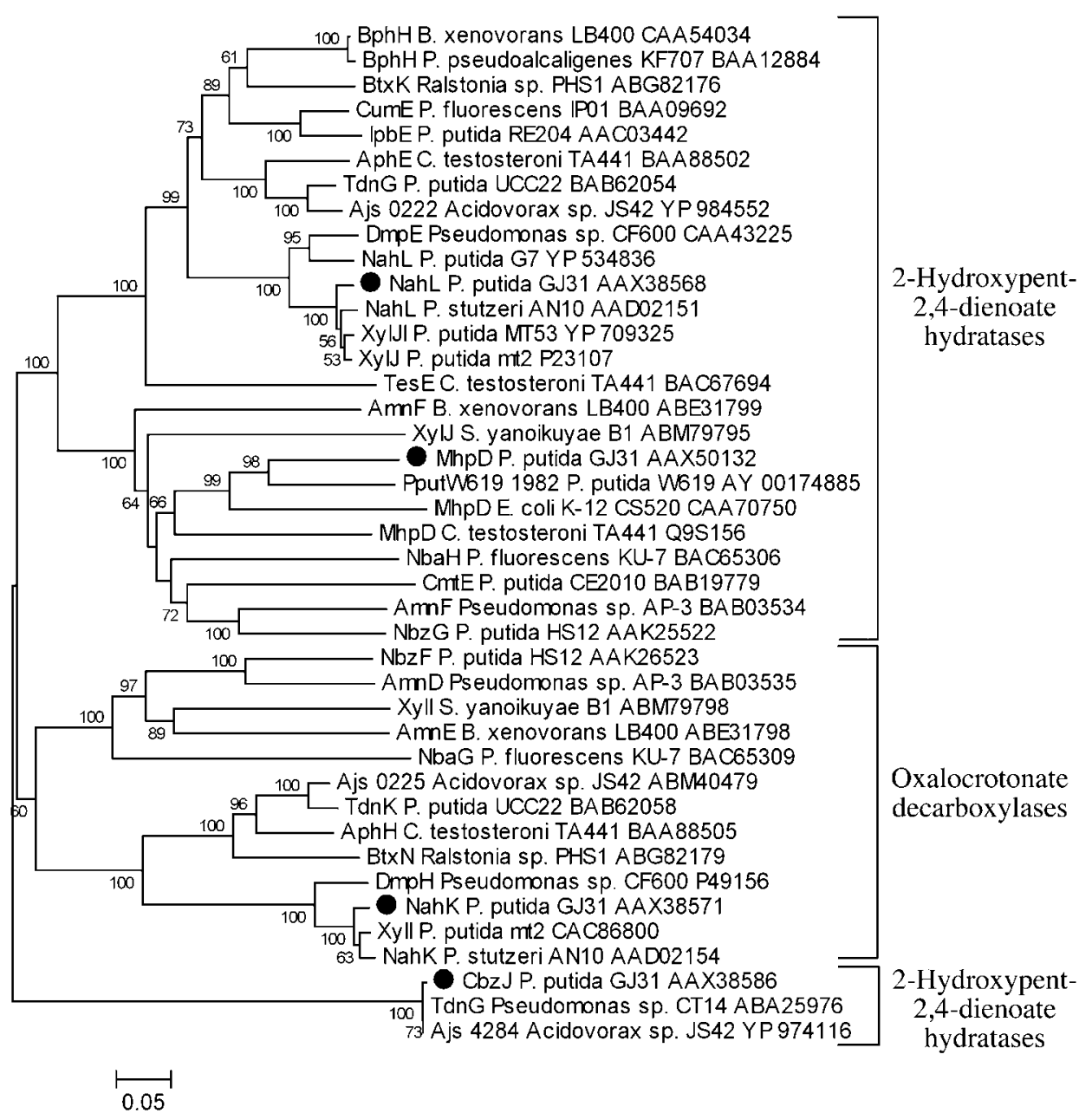

Fig. 3. Evolutionary relationships of 2-hydroxypent-2,4-dienoate hydratases and oxalocrotonate decarboxylases. The evolutionary histories were inferred using the neighbour-joining method and the p-distance model. All positions containing alignment gaps and missing data were eliminated only in pairwise sequence comparisons. Phylogenetic analyses were conducted in MEGA4 (Tamura et al., 2007). Bootstrap values above $50 \%$ from 100 neighbour-joining trees are indicated to the left of the nodes. Bar, 0.05 amino acid differences per site; $\bullet$, proteins of $P$. putida GJ31 identified in this study.

However, activity with 2,3-dihydroxyphenylpropionate was significantly higher (1.8-fold) than that with catechol, in accordance with the putative function of the protein. In contrast, activity of CbzE with 2,3-dihydroxyphenylpropionate was only $20 \%$ of that with catechol, as expected for a (chloro)catechol 2,3-dioxygenase. Like most catechol 2,3dioxygenases so far described, MhpB failed to convert 3chlorocatechol.

In accordance with the assumed function of the gene cluster as having evolved for the degradation of 2,3dihydroxyphenylpropionate, the protein (308 aa) encoded by $m h p C$ showed highest similarities with 2-hydroxy-6ketonona-2,4-dienoate hydrolases such as MphC of E. coli K-12 (73\%) (Ferrandez et al., 1997). Strong 2-hydroxymuconic semialdehyde hydrolase activity [1100 units (g protein $)^{-1}$ ] in E. coli (pXPF) expressing MhpC in comparison with the control proves $\operatorname{mhpC}$ to encode a functional hydrolase.

The deduced amino acid sequence (270 aa) of MhpD showed significant sequence similarities to the protein family of 4-oxalocrotonate hydratases/decarboxylases. High similarity was observed with MhpD 2-hydroxypent2,4-dienoate hydratases such as that of E. coli K-12 (66\%) (Ferrandez et al., 1997) (Fig. 3). Enzyme assays with crude extracts of E. coli (pXPJ2) expressing MhpD confirmed this enzyme to encode a hydratase, as evidenced by a strong activity [840 units (g protein) ${ }^{-1}$ ] with 2-hydroxypent-2,4dienoate and the absence of a 4-oxalocrotonate decarboxylase activity.

$m h p F$ encodes a protein of 312 aa sharing up to $84 \%$ identical residues with a previously reported acetaldehyde 


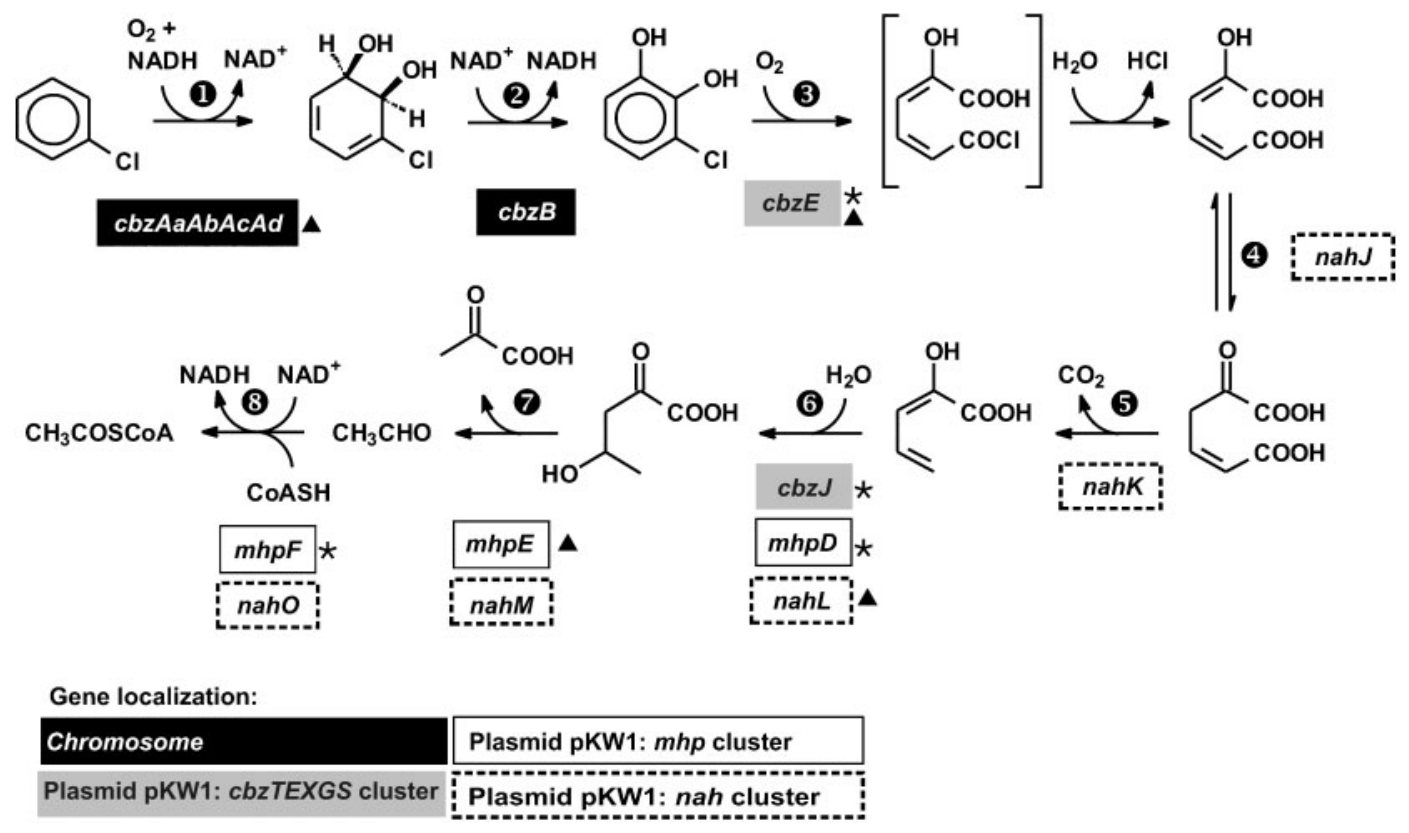

Fig. 4. Degradative pathway for chlorobenzene in P. putida strain GJ31. Enzymes involved are: 1, chlorobenzene dioxygenase; 2, chlorobenzene dihydrodiol dehydrogenase; 3 , extradiol dioxygenase; 4, oxalocrotonate tautomerase; 5 , oxalocrotonate decarboxylase; 6, 2-hydroxypent-2,4-dienoate hydratase; 7, 4-hydroxy-2-oxovalerate aldolase; 8, acetaldehyde dehydrogenase (acetylating). Asterisks indicate activity detected with an expression clone; $\boldsymbol{\Delta}$, RT-PCR determination of induction in the presence of chlorobenzene.

dehydrogenase integrated in proteobacterial meta-cleavage pathways (Yano et al., 2007). Analysis of cell extracts of $E$. coli (pXPQ) confirmed $m h p F$ to encode an acetaldehyde dehydrogenase, as evidenced by an activity of 350 units ( $\mathrm{g}$ protein $)^{-1}$, which was absent in the control lacking the $m h p F$ insert. Also, the protein (336 aa) encoded by $m h p E$ was most closely related to proteins of 2,3-dihydroxyphenylpropionate pathways and showed up to $88 \%$ identity with aldolases cleaving 4-hydroxy-2-oxovalerate to give pyruvate and acetaldehyde (Shingler et al., 1992). $\operatorname{mh} p R$, located $339 \mathrm{bp}$ upstream of $\operatorname{mhp} B$, is the only ORF transcribed in a direction opposite to the other genes of this cluster. Sequence comparisons indicate that MhpR belongs to the GntR family of transcriptional regulators, and significant similarity ( $37 \%$ identity) was observed with the OhpR regulator of the 2,3-dihydroxyphenylpropionate catabolic operon of Rhodococcus sp. strain V49 (Powell \& Archer, 1998). $\operatorname{mhpT}$ (403 aa) encodes a protein of the major facilitator superfamily (MFS), and the deduced protein sequence shows high similarity ( $>50 \%$ identity) to MhpT proteins assumed to be 3-hydroxypropionate transporters (e.g. P77589) and in Enterobacteriaceae typically encoded upstream of the 2,3-dihydroxyphenylpropionate pathway genes (e.g. AP009048). A genetic organization similar to the one observed here is also suggested to be present in P. putida W619 (NC_010501).

The deduced amino acid sequence (293 aa) of the incomplete $m h p P$ showed significant sequence similarities to porins of the Opr family, specifically to PaaM, which has been suggested to be involved in the uptake of phenylacetate by $P$. putida U ( $45 \%$ amino acid identity) (Olivera et al., 1998). Similar proteins are usually not encoded in 2,3-dihydroxyphenylpropionate catabolic gene clusters. Two ORFs were identified preceding the 2,3-dihydroxyphenylpropionate catabolic gene cluster (Table 3). However, their functions remain unknown.

Hybridization with probe QW09 (targeting $m h p E$ ) and probe QWS1 (targeting $c b z E$ ) showed both genes to be localized on a single $39 \mathrm{~kb}$ Asel fragment (Fig. 1). As probe QW09 also hybridized with a $21 \mathrm{~kb}$ AseI/SspI fragment, $m h p E$ is located on the part of the $m h p$ cluster near the $c b z E$ cluster, and all genes but $m h p R$ are oriented in the opposite direction to the $c b z E$ cluster.

\section{Plasmid pKW1 harbours an incomplete nah cluster}

Genes encoding 4-oxalocrotonate tautomerase and 4oxalocrotonate decarboxylase, necessary for the conversion of 2-hydroxymuconate, the 3-chlorocatechol ring-cleavage product, to 2-hydroxypent-2,4-dienoate, were absent in both of the aforementioned gene clusters (see Fig. 4). To search for respective genes, conserved regions of oxalocrotonate decarboxylase-encoding genes were used for the design of the primer pair Kay4/Kay5 (see Table 2). A $0.79 \mathrm{~kb}$ PCR fragment obtained with pKW1 DNA as 
template was sequenced, and a total of $5943 \mathrm{bp}$ of sequence framing this fragment was analysed after PCR-based walking.

The analysed gene region (Fig. 1d) showed high identity $(96 \%)$ over the whole sequence to the region encoding NahINLOMKJ of the nahGTHINLOMKJ gene cluster of Pseudomonas stutzeri AN10 (Bosch et al., 2000). As the protein sequence differences did not involve amino acids assumed to be crucial for enzyme activity, the analysed region can be assumed to encode the following: NahI, 2hydroxymuconic semialdehyde dehydrogenase (incomplete); NahN, 2-hydroxymuconic semialdehyde hydrolase; NahL, 2-hydroxypent-2,4-dienoate hydratase; NahO, acetaldehyde dehydrogenase (acylating); NahM, 4-hydroxy-2oxovalerate aldolase; NahK, oxalocrotonate decarboxylase; and NahJ, oxalocrotonate tautomerase. The function of NahX (147 aa) remains unknown. Screening upstream of nahI using primers Exdo-A-F2/NahI-R1 (Table 2), designed based on a multiple sequence alignment of currently available subfamily I.2.A catechol 2,3-dioxygenases and the available nahI sequence of GJ31, gave no indication of the presence of a $\mathrm{NahH}$ catechol 2,3dioxygenase-encoding gene. However, a PCR product of the expected $1061 \mathrm{bp}$ was observed using total DNA of Pseudomonas sp. 1dBTEX2 (Junca \& Pieper, 2004) as the control. Similarly, PCR products of the expected length (421 and $716 \mathrm{bp}$ ) were observed with primer pairs Exdo-AF/Exdo-A-R1 and Exdo-A-F/Exdo-A-R719, respectively, using only Pseudomonas sp. 1dBTEX2 DNA as the template, indicating the absence of a gene encoding a subfamily I.2.A catechol 2,3-dioxygenase from the genome of P. putida GJ31.

\section{The upper pathway genes are located on the chromosome}

The degradation of chlorobenzenes in strains employing an ortho-cleavage pathway is typically initiated by a Rieske non-haem iron oxygenase of the toluene/biphenyl subfamily. Primers Qno13 and Qno14, targeting conserved regions in the toluene/biphenyl oxygenase, amplified a $2.8 \mathrm{~kb}$ fragment termed QW04, when total DNA of strain GJ31 was used as template. The fragment was sequenced and gene walking applied to obtain a total of $5493 \mathrm{bp}$ of sequence information framing QW04.

The analysed gene region (Fig. 1e) showed $99 \%$ sequence identity to the TodC1C2BADE-encoding gene region of $P$. putida F1 (Zylstra \& Gibson, 1989). Accordingly, a total of six ORFs, termed $c b z A a, c b z A b, c b z A c, c b z A d, c b z B$ and $c b z E 2$, could be identified, with the first four clearly encoding the $\alpha$ - and $\beta$-subunits, ferredoxin and $\mathrm{NADH}$ : ferredoxin oxidoreductase of chlorobenzene dioxygenase, respectively. Whereas $\mathrm{CbzAb}$ and $\mathrm{CbzB}$ were identical to TodC2 and TodB, respectively, CbzAa, CbzAd and $\mathrm{CbzD}$ differed from the orthologous Tod proteins by only a single amino acid each. As these differences are localized in regions not crucial for protein performance
(Friemann et al., 2009) or constitute conservative amino acid differences (Hülsmeyer et al., 1998), it can be assumed that all encoded proteins are functional and similar in substrate specificity to those described from strain F1 and are capable of transforming chlorobenzene to 3-chlorocatechol (Gibson et al., 1968) sufficiently to allow growth on chlorobenzene (Ravatn et al., 1998) (see Fig. 4). CbzE2, like TecE of Ralstonia sp. PS12 (Beil et al., 1999), shows a onebase deletion at position 277 compared with the todE sequence, probably resulting in an inactive enzyme. Probe QW04a targeting chlorobenzene dioxygenase-encoding genes failed to hybridize with DNA of plasmid pKW1, the single plasmid in strain GJ31, confirming the upper pathway operon to be located on the chromosome.

\section{Transcription of pathway segments}

To analyse whether genes of the above-described gene clusters were transcribed in response to chlorobenzene, RTPCR experiments were performed with total RNA extracted from strain GJ31 growing on fructose or chlorobenzene using primers targeting $c b z A a, c b z E, m h p B, m h p E$ and $n a h L$. While transcripts of $n a h L$ and $c b z E$ were, like the housekeeping gene gltA encoding citrate synthase (Wehmhöner et al., 2003), detectable after growth on fructose in amounts of less than $10 \mathrm{ng}$ cDNA, transcripts of $c b z A a$ as well as of $m h p B$ and $m h p E$ were only detectable at 100 ng of cDNA template. More importantly, with regard to total RNA, transcript levels of $c b z E$ and $c b z A a$ in chlorobenzene-grown cells were increased by more than two orders of magnitude compared with fructose-grown cells, and those of $m h p B, m h p E$ and nahL by more than one order of magnitude. When the relative levels of transcripts were normalized with respect to the level of $g l t A$ transcripts, it was evident that the levels of both the $c b z E$ and the $c b z A a$ transcripts were significantly increased, but those of genes within the nah and mhp gene cluster only increased by twoto fourfold (Table 4).

\section{DISCUSSION}

The aerobic degradation of chlorobenzenes, in all strains characterized in this aspect so far, is initiated by a Rieske non-haem iron oxygenase of the toluene/biphenyl family (Gibson \& Parales, 2000; Reineke, 1998; Witzig et al., 2006). These enzymes are typically of relatively broad substrate specificity (Gibson \& Parales, 2000) and, as an example, toluene dioxygenase of $P$. putida F1 accepts, besides toluene, also chlorobenzene, $p$-chlorotoluene and 1,2-dichlorobenzene as substrates (Beil et al., 1998; Gibson et al., 1968).

The cbzAaAbAcAdBE2 cluster of strain GJ31, encoding chlorobenzene dioxygenase, dihydrodiol dehydrogenase and catechol 2,3-dioxygenase is of a structure identical to those of chlorobenzene upper pathway catabolic operons, such as those identified in Ralstonia sp. PS12 (Beil et al., 1997) and Acidovorax sp. P51 (van der Meer et al., 1991), 


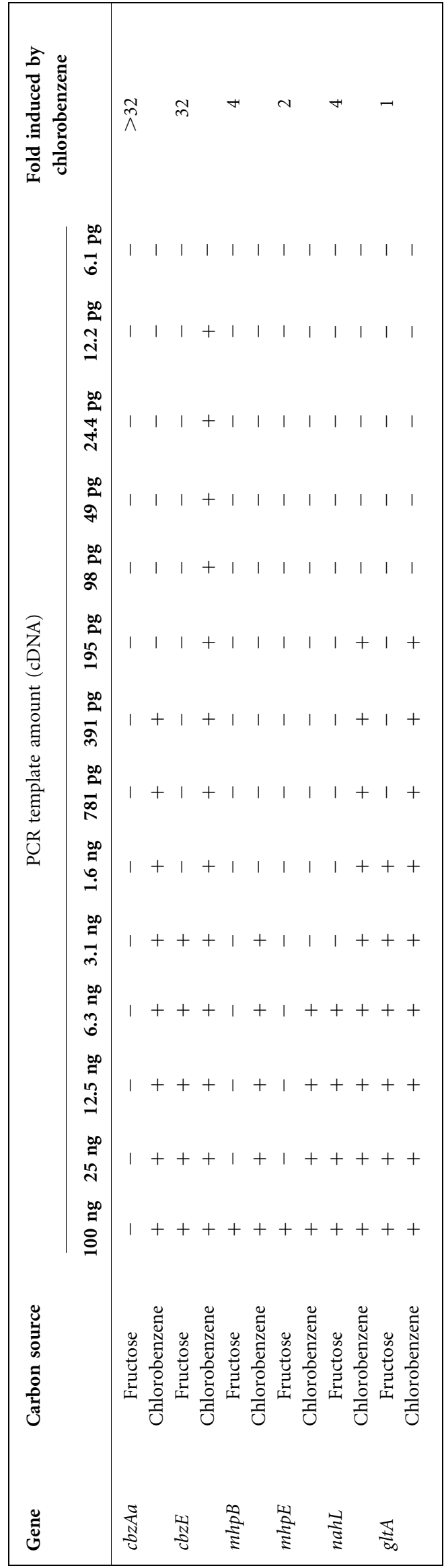

and nearly identical in sequence $(5478 / 5494 \mathrm{nt})$ to the todC1C2BADE cluster of $P$. putida strain F1 growing with toluene via a meta-cleavage pathway (Mosqueda et al., 1999; Zylstra \& Gibson, 1989), and the high level of transcription in response to chlorobenzene validated its involvement in chlorobenzene degradation by strain GJ31. Typically, in chlorobenzene degraders, the respective upper pathway gene clusters are combined with a chlorocatechol gene cluster so that degradation can proceed via chlorocatechols and a chlorocatechol ortho-cleavage pathway. As an example, the events of the evolution of a chlorobenzene pathway in Ralstonia sp. JS705 have been traced as the recombination of two pathway segments from two different ancestors to form one large catabolic gene region (Müller et al., 2003). The high mobility of upper pathway genes is further evidenced by the fact that the upper pathway genes on plasmid pP51 of Acidovorax sp. strain P51 (van der Meer et al., 1991) and in Ralstonia sp. strain PS12 (Beil et al., 1999; Müller et al., 2003) are carried on transposons, or are localized on genomic islands, as in Bordetella petrii (Gross et al., 2008). Whether the upper pathway genes of strain GJ31 belong to its core genome or have been recruited by horizontal gene transfer remains to be elucidated.

In strains degrading toluene via initial dioxygenation, such as $P$. putida F1 and $P$. putida DOT-T1, a complete hydrolytic branch of a meta-cleavage pathway is encoded by the same pathway gene cluster that encodes enzymes for initial dioxygenation and dehydrogenation (Lau et al., 1994; Menn et al., 1991; Mosqueda et al., 1999). However, chloroaromatic degraders have been reported to avoid the presence of an active extradiol dioxygenase. In the case of strain P51, point mutations leading to a frameshift, or the introduction of stop codons in the case of strain PS12, have caused inactivation of the disadvantageous meta-cleavage genes for chlorobenzene degradation (Beil et al., 1999). Such a defect in the catechol 2,3-dioxygenase is also found in CbzE2 of strain GJ31, indicating that the chromosomally encoded upper pathway evolved for chlorobenzene degradation. The absence of a gene encoding a functional extradiol dioxygenase will typically result in the concomitant loss of the ability to degrade toluene in organisms that break down chlorobenzene via a chlorocatechol orthocleavage pathway, since methylaromatics can be degraded by ortho-cleavage pathways only in extraordinary cases (Rojo et al., 1987). Here, the recruitment of a chlorocatechol meta-cleavage pathway has equipped strain GJ31 with the capability to degrade both chlorobenzene and toluene (Mars et al., 1997), despite a non-functional extradiol dioxygenase in the upper pathway gene cluster.

Various features of the cbzTEXGS cluster of strain GJ31 deserve special attention. The coding and non-coding regions are nearly identical to the clusters of other chlorobenzene-degrading organisms using a meta-cleavage pathway (Göbel et al., 2004), and contain only an incomplete meta-cleavage pathway. Significant induction of $\mathrm{CbzE}$ in response to chlorobenzene was observed, but 
also a high level of transcripts even in fructose-grown cells, which may prevent accumulation of toxic catechols (Schweigert et al., 2001). CbzE is part of the subfamily I.2.C of extradiol dioxygenases (Eltis \& Bolin, 1996). Various genes encoding enzymes of this subfamily have been recently identified, including in the course of genome sequencing projects (e.g. Leptothrix cholodnii SP-6, NC_010524; Acidovorax sp. JS42, NC_008782; Verminephrobacter eiseniae EF01-2, NC_008786; C. necator JMP134, NC_007348). From such accumulated knowledge, gene clusters comprising genes encoding subfamily I.2.C extradiol dioxygenases typically encode enzymes of both the hydrolytic and the oxalocrotonate branch of the metacleavage pathway. Only part of the conserved structure is retained in the form of the cbzTEXG genes, and a GSTencoding gene has not been observed to be encoded in other clusters that contain genes encoding subfamily I.2.C extradiol dioxygenases. These clusters are typically preceded by genes encoding either an aniline dioxygenase (Fukumori \& Saint, 2001; Urata et al., 2004) or a multicomponent phenol hydroxylase (Zhu et al., 2008). Due to the presence of 177 bases in front of the ferredoxin gene homologous to genes encoding the NADH oxidoreductase of multicomponent phenol hydroxylase, it can be suggested that the $c b z$ cluster was recruited from such a source.

Although downstream of the $c b z E$ cluster $c b z J$ encodes a functional and novel type of 2-hydroxypent-2,4-dienoate hydratase, the origin of which remains to be established, the $c b z E$ cluster in concert with the upper pathway gene cluster is not sufficient to allow mineralization of chlorobenzene via 2-hydroxymuconate as an intermediate (Fig. 4). Two additional catabolic gene clusters, which could partially ( $m h p$ gene cluster) or completely (nah gene cluster) fulfil the role of creating a complete pathway, could be identified here. However, the transcription of both gene clusters was only slightly elevated in response to chlorobenzene. Nevertheless, the significant level of transcription of the nah gene cluster even in the absence of chlorobenzene supports the notion that it is responsible for completion of the metabolic route.

The chlorobenzene degradative pathway in strain GJ31 (Fig. 4) thus seems to be a mosaic constructed of (i) a chromosomal toluene pathway, (ii) a phenol metabolic cluster for the recruitment of $c b z E$, (iii) a phenylpropionate pathway, and (iv) an incomplete NAH pathway. Strain GJ31 is an example of an organism obtained from enrichment cultures able to use a chloroaromatic compound as the growth substrate in which the degradative pathway is the product of patchwork assembly.

\section{ACKNOWLEDGEMENTS}

This work was financed by a grant from the Deutsche Forschungsgemeinschaft (Re659/7) and by the European Union, contract EVK1-CT1999-00023 'MAROC'. We thank Professor Timothy D. H. Bugg, University of Warwick, for a sample of 2,3- dihydroxyphenylpropionate and Melissa Wos-Oxley for critical reading of the manuscript.

\section{REFERENCES}

Barnes, M. R., Duetz, W. A. \& Williams, P. A. (1997). A 3-(3hydroxyphenyl)propionic acid catabolic pathway in Rhodococcus globerulus PWD1: cloning and characterization of the $h p p$ operon. J Bacteriol 179, 6145-6153.

Bartels, F., Backhaus, S., Moore, E. R. B., Timmis, K. N. \& Hofer, B. (1999). Occurrence and expression of glutathione-S-transferaseencoding $b p h K$ genes in Burkholderia sp. strain LB400 and other biphenyl-utilizing bacteria. Microbiology 145, 2821-2834.

Beil, S., Happe, B., Timmis, K. N. \& Pieper, D. H. (1997). Genetic and biochemical characterization of the broad-spectrum chlorobenzene dioxygenase from Burkholderia sp. strain PS12: dechlorination of 1,2,4,5-tetrachlorobenzene. Eur J Biochem 247, 190-199.

Beil, S., Mason, J. R., Timmis, K. N. \& Pieper, D. H. (1998). Identification of chlorobenzene dioxygenase sequence elements involved in dechlorination of 1,2,4,5-tetrachlorobenzene. J Bacteriol 180, 5520-5528.

Beil, S., Timmis, K. N. \& Pieper, D. H. (1999). Genetic and biochemical analyses of the tec operon suggest a route for evolution of chlorobenzene degradation genes. J Bacteriol 181, 341-346.

Bosch, R., Garcia-Valdes, E. \& Moore, E. R. B. (2000). Complete nucleotide sequence and evolutionary significance of a chromosomally encoded naphthalene-degradation lower pathway from Pseudomonas stutzeri AN10. Gene 245, 65-74.

Bradford, M. M. (1976). A rapid and sensitive method for the quantitation of protein utilizing the principle of protein-dye binding. Anal Biochem 72, 248-254.

Bramucci, M., Chen, M. \& Nagarajan, V. (2006). Genetic organization of a plasmid from an industrial wastewater bioreactor. Appl Microbiol Biotechnol 71, 67-74.

Bugg, T. D. H. (1993). Overproduction, purification and properties of 2,3-dihydroxyphenylpropionate 1,2-dioxygenase from Escherichia coli. Biochim Biophys Acta 1202, 258-264.

Collinsworth, W. L., Chapman, P. J. \& Dagley, S. (1973). Stereospecific enzymes in the degradation of aromatic compounds by Pseudomonas putida. J Bacteriol 113, 922-931.

Diaz, E., Ferrandez, A., Prieto, M. A. \& Garcia, J. L. (2001). Biodegradation of aromatic compounds by Escherichia coli. Microbiol Mol Biol Rev 65, 523-569.

Dorn, E. \& Knackmuss, H.-J. (1978a). Chemical structure and biodegradability of halogenated aromatic compounds. Two catechol 1,2-dioxygenases from a 3-chlorobenzoate-grown pseudomonad. Biochem J 174, 73-84.

Dorn, E. \& Knackmuss, H.-J. (1978b). Chemical structure and biodegradability of halogenated aromatic compounds. Substituent effects on 1,2-dioxygenation of catechol. Biochem J 174, 85-94.

Eltis, L. D. \& Bolin, J. T. (1996). Evolutionary relationships among extradiol dioxygenases. J Bacteriol 178, 5930-5937.

Ferrandez, A., Garcia, J. L. \& Diaz, E. (1997). Genetic characterization and expression in heterologous hosts of the 3-(3-hydroxyphenyl)propionate catabolic pathway of Escherichia coli K-12. J Bacteriol 179, 2573-2581.

Friemann, R., Lee, K., Brown, E. N., Gibson, D. T., Eklund, H. \& Ramaswamy, S. (2009). Structures of the multicomponent Rieske non-heme iron toluene 2,3-dioxygenase enzyme system. Acta Crystallogr D Biol Crystallogr 65, 24-33. 
Fukumori, F. \& Saint, C. P. (2001). Complete nucleotide sequence of the catechol metabolic region of plasmid pTDN1. J Gen Appl Microbiol 47, 329-333.

Gibson, D. T. \& Parales, R. E. (2000). Aromatic hydrocarbon dioxygenases in environmental biotechnology. Curr Opin Biotechnol 11, 236-243.

Gibson, D. T., Koch, J. R., Schuld, C. L. \& Kallio, R. E. (1968). Oxidative degradation of aromatic hydrocarbons by microorganisms. II. Metabolism of halogenated aromatic hydrocarbons. Biochemistry 7, 3795-3802.

Göbel, M., Kranz, O. H., Kaschabek, S. R., Schmidt, E., Pieper, D. H. \& Reineke, W. (2004). Microorganisms degrading chlorobenzene via a meta-cleavage pathway harbor highly similar chlorocatechol 2,3-dioxygenase-encoding gene clusters. Arch Microbiol 182, 147156.

Gross, R., Guzman, C. A., Sebaihia, M., dos Santos, V. A., Pieper, D. H., Koebnik, R., Lechner, M., Bartels, D., Buhrmester, J. \& other authors (2008). The missing link: Bordetella petrii is endowed with both the metabolic versatility of environmental bacteria and virulence traits of pathogenic Bordetellae. BMC Genomics 9, 449.

Hanahan, D. (1983). Studies on transformation of Escherichia coli with plasmids. J Mol Biol 166, 557-580.

Herrmann, H., Lauf, U. \& Müller, C. (1998). The transposable elements resident on the plasmids of Pseudomonas putida strain $\mathrm{H}, \mathrm{Tn} 5501$ and Tn5502, are cryptic transposons of the Tn3 family. Mol Gen Genet 259, 674-678.

Hülsmeyer, M., Hecht, H. J., Niefind, K., Hofer, B., Eltis, L. D., Timmis, K. N. \& Schomburg, D. (1998). Crystal structure of cis-biphenyl-2,3dihydrodiol-2,3-dehydrogenase from a PCB degrader at $2.0 \AA$ resolution. Protein Sci 7, 1286-1293.

Junca, H. \& Pieper, D. H. (2004). Functional gene diversity analysis in BTEX contaminated soils by means of PCR-SSCP DNA fingerprinting: comparative diversity assessment against bacterial isolates and PCR-DNA clone libraries. Environ Microbiol 6, 95-110.

Kaschabek, S. R. \& Reineke, W. (1992). Maleylacetate reductase of Pseudomonas sp. strain B13: dechlorination of chloromaleylacetates, metabolites in the degradation of chloroaromatic compounds. Arch Microbiol 158, 412-417.

Kaschabek, S. R., Kasberg, T., Müller, D., Mars, A. E., Janssen, D. B. \& Reineke, W. (1998). Degradation of chloroaromatics: purification and characterization of a novel type of chlorocatechol 2,3-dioxygenase of Pseudomonas putida GJ31. J Bacteriol 180, 296-302.

Lau, P. C. K., Bergeron, H., Labbe, D., Wang, Y., Brousseau, R. \& Gibson, D. T. (1994). Sequence and expression of the todGIH genes involved in the last three steps of toluene degradation by Pseudomonas putida F1. Gene 146, 7-13.

Lauf, U., Müller, C. \& Herrmann, H. (1998). The transposable elements resident on the plasmids of Pseudomonas putida strain H, Tn5501 and Tn5502, are cryptic transposons of the Tn3 family. Mol Gen Genet 259, 674-678.

Mars, A. E., Kasberg, T., Kaschabek, S. R., van Agteren, M. H., Janssen, D. B. \& Reineke, W. (1997). Microbial degradation of chloroaromatics: use of the meta-cleavage pathway for mineralization of chlorobenzene. J Bacteriol 179, 4530-4537.

Mars, A. E., Kingma, J., Kaschabek, S. R., Reineke, W. \& Janssen, D. B. (1999). Conversion of 3-chlorocatechol by various catechol 2,3dioxygenases and sequence analysis of the chlorocatechol dioxygenase region of Pseudomonas putida GJ31. J Bacteriol 181, 1309-1318.

Menn, F.-M., Zylstra, G. J. \& Gibson, D. T. (1991). Location and sequence of the todF gene encoding 2-hydroxy-6-oxohepta-2,4dienoate hydrolase in Pseudomonas putida. Gene 104, 91-94.
Mosqueda, G., Ramos-Gonzalez, M. I. \& Ramos, J. L. (1999). Toluene metabolism by the solvent-tolerant Pseudomonas putida DOT-T1 strain, and its role in solvent impermeabilization. Gene 232, 69-76.

Müller, T. A., Werlen, C., Spain, J. \& van der Meer, J. R. (2003). Evolution of a chlorobenzene degradative pathway among bacteria in a contaminated groundwater mediated by a genomic island in Ralstonia. Environ Microbiol 5, 163-173.

Nozaki, M. (1970). Metapyrocatechase (Pseudomonas). Methods Enzymol 17A, 522-525.

Oldenhuis, R., Kuijk, L., Lammers, A., Janssen, D. B. \& Witholt, B. (1989). Degradation of chlorinated and non-chlorinated aromatic solvents in soil suspension by pure bacterial cultures. Appl Microbiol Biotechnol 30, 211-217.

Olivera, E. R., Minambres, B., Garcia, B., Muniz, C., Moreno, M. A., Ferrandez, A., Diaz, E., Garcia, J. L. \& Luengo, J. M. (1998). Molecular characterization of the phenylacetic acid catabolic pathway in Pseudomonas putida U: the phenylacetyl-CoA catabolon. Proc Natl Acad Sci U S A 95, 6419-6424.

Peters, M., Heinaru, E., Talpsep, E., Wand, H., Stottmeister, U., Heinaru, A. \& Nurk, A. (1997). Acquisition of a deliberately introduced phenol degradation operon, pheBA, by different indigenous Pseudomonas species. Appl Environ Microbiol 63, 4899-4906.

Poelarends, G. J., Veetil, V. P. \& Whitman, C. P. (2008). The chemical versatility of the $\beta-\alpha-\beta$ fold: catalytic promiscuity and divergent evolution in the tautomerase superfamily. Cell Mol Life Sci 65, 36063618.

Pohlman, R. F., Genetti, H. D. \& Winans, S. C. (1994). Entry exclusion of the IncN plasmid pKM101 is mediated by a single hydrophilic protein containing a lipid attachment motif. Plasmid 31, 158-165.

Powell, J. A. C. \& Archer, J. A. C. (1998). Molecular characterisation of a Rhodococcus ohp operon. Antonie Van Leeuwenhoek 74, 175-188.

Providenti, M. A., Shaye, R. E., Lynes, K. D., McKenna, N. T., O’Brien, J. M., Rosolen, S., Wyndham, R. C. \& Lambert, I. B. (2006). The locus coding for the 3-nitrobenzoate dioxygenase of Comamonas sp. strain JS46 is flanked by IS1071 elements and is subject to deletion and inversion events. Appl Environ Microbiol 72, 2651-2660.

Ravatn, R., Studer, S., Springael, D., Zehnder, A. J. B. \& van der Meer, J. R. (1998). Chromosomal integration, tandem amplification, and deamplification in Pseudomonas putida F1 of a 105-kilobase genetic element containing the chlorocatechol degradative genes from Pseudomonas sp. strain B13. J Bacteriol 180, 4360-4369.

Reineke, W. (1998). Development of hybrid strains for the mineralization of chloroaromatics by patchwork assembly. Annu Rev Microbiol 52, 287-331.

Reineke, W. (2001). Aerobic and anaerobic biodegradation potentials of microorganisms. In Biodegradation and Persistence (The Handbook of Environmental Chemistry, vol. 2K), pp. 1-161. Edited by B. Beek. Berlin/Heidelberg: Springer Verlag.

Rojo, F., Pieper, D. H., Engesser, K.-H., Knackmuss, H.-J. \& Timmis, K. N. (1987). Assemblage of ortho cleavage route for simultaneous degradation of chloro- and methylaromatics. Science 238, 1395-1398.

Saitou, N. \& Nei, M. (1987). The neighbor-joining method: a new method for reconstructing phylogenetic trees. Mol Biol Evol 4, 406425.

Sambrook, J., Fritsch, E. F. \& Maniatis, T. (1989). Molecular Cloning: a Laboratory Manual, 2nd edn. Cold Spring Harbor, NY: Cold Spring Harbor Laboratory.

Schmidt, E. \& Knackmuss, H.-J. (1980). Chemical structure and biodegradability of halogenated aromatic compounds. Conversion of chlorinated muconic acids into maleoylacetic acid. Biochem J 192, 339-347. 
Schmidt, E., Remberg, G. \& Knackmuss, H.-J. (1980). Chemical structure and biodegradability of halogenated aromatic compounds. Halogenated muconic acids as intermediates. Biochem J 192, 331-337.

Schwarzenbach, R. P., Gschwend, P. M. \& Imboden, D. M. (2003). Environmental Organic Chemistry, 2nd edn. Hoboken, NJ: WileyInterscience.

Schweigert, N., Zehnder, A. J. B. \& Eggen, R. I. L. (2001). Chemical properties of catechols and their molecular modes of toxic action in cells, from microorganisms to mammals. Environ Microbiol 3, 81-91.

Sherratt, D. (1989). Tn 3 and related transposable elements: sitespecific recombination and transposition. In Mobile DNA, pp. 13021308. Edited by D. E. Berg \& M. M. Howe. Washington, DC: American Society for Microbiology.

Shingler, V., Powlowski, J. \& Marklund, U. (1992). Nucleotide sequence and functional analysis of the complete phenol/3,4dimethylphenol catabolic pathway of Pseudomonas sp. strain CF600. J Bacteriol 174, 711-724.

Sota, M., Yano, H., Nagata, Y., Ohtsubo, Y., Genka, H., Anbutsu, H., Kawasaki, H. \& Tsuda, M. (2006). Functional analysis of unique class II insertion sequence IS1071. Appl Environ Microbiol 72, 291-297.

Stanley, T. M., Johnson, W. H., Burks, E. A., Whitman, C. P., Hwang, C. C. \& Cook, P. F. (2000). Expression and stereochemical and isotope effect studies of active 4-oxalocrotonate decarboxylase. Biochemistry 39, 3514.

Tamura, K., Dudley, J., Nei, M. \& Kumar, S. (2007). MEGA4: Molecular Evolutionary Genetics Analysis (MEGA) software version 4.0. Mol Biol Evol 24, 1596-1599.

Tropel, D., Meyer, C., Armengaud, J. \& Jouanneau, Y. (2002). Ferredoxin-mediated reactivation of the chlorocatechol 2,3-dioxygenase from Pseudomonas putida GJ31. Arch Microbiol 177, 345-351.

Urata, M., Uchida, E., Nojiri, H., Omori, T., Obo, R., Miyaura, N. \& Ouchiyama, N. (2004). Genes involved in aniline degradation by Delftia acidovorans strain $7 \mathrm{~N}$ and its distribution in the natural environment. Biosci Biotechnol Biochem 68, 2457-2465.

van der Meer, J. R., Zehnder, A. J. B. \& de Vos, W. M. (1991). Identification of a novel composite transposable element, Tn5280, carrying chlorobenzene dioxygenase genes of Pseudomonas sp. strain P51. J Bacteriol 173, 7077-7083.
Volff, J. N., Eichenseer, C., Viell, P., Piendl, W. \& Altenbuchner, J. (1996). Nucleotide sequence and role in DNA amplification of the direct repeats composing the amplificable element AUD1 of Streptomyces lividans 66. Mol Microbiol 21, 1037-1047.

Wackett, L. P. \& Hershberger, C. D. (2001). Biocatalysis and biodegradation. Microbial Transformation of Organic Compounds. Washington, DC: American Society for Microbiology.

Wehmhöner, D., Häussler, S., Tümmler, B., Jänsch, L., Bredenbruch, F., Wehland, J. \& Steinmetz, I. (2003). Inter- and intraclonal diversity of the Pseudomonas aeruginosa proteome manifests within the secretome. $J$ Bacteriol 185, 5807-5814.

Wheatcroft, R. \& Williams, P. A. (1981). Rapid methods for the study of both stable and unstable plasmids in Pseudomonas. J Gen Microbiol 124, 433-437.

Witzig, R., Junca, H., Hecht, H. J. \& Pieper, D. H. (2006). Assessment of toluene/biphenyl dioxygenase gene diversity in benzene-polluted soils: links between benzene biodegradation and genes similar to those encoding isopropylbenzene dioxygenases. Appl Environ Microbiol 72, 3504-3514.

Witzig, R., Aly, H. A., Strömpl, C., Wray, V., Junca, H. \& Pieper, D. H. (2007). Molecular detection and diversity of novel diterpenoid dioxygenase DitAl genes from proteobacterial strains and soil samples. Environ Microbiol 9, 1202-1218.

Yano, H., Garruto, C. E., Sota, M., Ohtsubo, Y., Nagata, Y., Zylstra, G. J., Williams, P. A. \& Tsuda, M. (2007). Complete sequence determination combined with analysis of transposition/site-specific recombination events to explain genetic organization of IncP-7 TOL plasmid pWW53 and related mobile genetic elements. J Mol Biol 369, $11-26$.

Zhu, C., Zhang, L. \& Zhao, L. (2008). Molecular cloning, genetic organization of gene cluster encoding phenol hydroxylase and catechol 2,3-dioxygenase in Alcaligenes faecalis IS-46. World $J$ Microbiol Biotechnol 24, 1687-1695.

Zylstra, G. J. \& Gibson, D. T. (1989). Toluene degradation by Pseudomonas putida F1. Nucleotide sequence of the todC1C2BADE genes and their expression in Escherichia coli. J Biol Chem 264, 1494014946.

Edited by: H. L. Drake 